\title{
Two Stay Two Stray (TSTS) Learning Model Assisted with Mind Mapping Improving Students' Social Studies Learning Outcomes
}

\section{Ni Putu Sawitri Ekayani ${ }^{1}$, I Made Suarjana ${ }^{2}$, I Nyoman Laba Jayanta ${ }^{3}$}

123 Primary School Teacher Education Study Program, Ganesha University of Education, Singaraja, Bali, Indonesia

\author{
ARTICLEINFO \\ Article history: \\ Received 2 Juni 2020 \\ Received in revised form \\ 12 Juli 2020 \\ Accepted 10 Agustus 2020 \\ Available online 28 Agustus \\ 2020 \\ kata kunci: \\ two stay two stray, mind \\ mapping, hasil belajar IPS \\ keywords: \\ two stay two stray, mind \\ mapping, learning outcomes
}

\begin{abstract}
A B S T R A K
Penelitian ini memiliki tujuan untuk mengetahui pengaruh model pembelajaran Two Stay Two Stray (TSTS) berbantuan media mind mapping terhadap hasil belajar IPS siswa kelas V. Penelitian ini termasuk jenisquasi eksperimen dengan rancangan penelitian nonequivalent posttest only control group design. Populasi penelitian ini adalah seluruh kelas V SD di Gugus I Kecamatan Bangli yang berjumlah 7 kelas dengan total siswa 138 orang. Sampel penelitian ini diambil dengan teknik simple random sampling sehingga diperoleh kelas V SD N 2 Tamanbali yang berjumlah 20 siswa sebagai kelompok eksperimen dan kelas V SD N 1 Tamanbali yang berjumlah 30 siswa sebagai kelompok kontrol. Teknik analisis data dalam penelitian ini menggunakan teknik analisis statistik deskriptif dan uji prasyarat analisis data. Pengujian hipotesis menggunakan uji $t$-test polled varians. Hasil perhitungan rata-rata hasil belajar IPS siswa kelompok eksperimen yaitu 23,15 termasuk kategori sangat tinggi, sedangkan siswa pada kelompok kontrol memiliki nilai rata-
\end{abstract}

rata 17,23 termasuk kategori sedang. Berdasarkan perhitungan dengan uji-t didapatkan $t_{\text {hitung }}$ sebesar 4,89 lebih besar dari nilai tabel yaitu 2,010 dengan dk sebesar 48, pada taraf signifikansi 5\%. Dari hasil analisis tersebut dapat disimpulkan bahwa terdapat pengaruh yang signifikan model pembelajaran Two Stay Two Stray (TSTS) berbantuan media mind mapping terhadap hasil belajar IPS siswa kelas V. Maka dari itu model pembelajaran TSTS berbantuan media mind mapping cocok diterapkan untuk meningkatkan hasil belajar IPS siswa.

\begin{abstract}
A B S T R A C T
This research aimed to analyze the effect of the Two Stay Two Stray (TSTS) learning model assisted with mind mapping media toward social studies learning outcomes in Grade V. The type of this research was a quasiexperimental research design with nonequivalent post-test only controls group design. The population of this research was all of the fifth-grade elementary schools in Cluster I Bangli District, which totaled 7 classes with 138 students. The samples were determined using a simple random sampling technique, totaling 20 students as the experimental group and 30 students as the control group. Data analysis techniques in this research used descriptive statistical analysis techniques and data analysis prerequisite tests. Hypothesis analysis used the ttest polled variance test. The results of the calculation of the average social studies learning outcomes of the experimental group students were 23.15 included in the very high category, while students in the control group had an average value of 17.23 including the moderate category. Based on calculations with the t-test obtained a t-count of 4.89 is greater than the t-table value of 2.010 with a dk of 48 , at a significance level of $5 \%$. From the results of the analysis, it can be concluded that the Two Stay Two Stray (TSTS) learning model assisted with mind mapping media has a significant effect on social studies learning outcomes for fifth-grade elementary school students. Therefore, the TSTS learning model assisted with mind mapping media is suitable to be applied to improve students' social studies learning outcomes.
\end{abstract}

\section{Introduction}

Learning is an activity organized to facilitate and support students in their learning activities, which have been arranged and designed coherently or systematically (Sutrisno \& Siswanto, 2016). One of the learning activities held in class is Social Science (IPS) learning. Social Science is a study of social sciences that have been put together and simplified which are then applied in learning (Fajarini, 2018). IPS is taught at every level of education, whether at the primary, secondary, or higher education levels. Currently, there are more and more challenges that students encounter in

Copyright (C) Universitas Pendidikan Ganesha. All rights reserved. 
their daily lives and are related to social problems, therefore social studies learning has the objective of being able to develop students' social skills (Nurhasanah, 2016). Those way students will be able to develop positive values and attitudes to be able to solve social problems that occur and find the right solutions to overcome them.

According to Christina \& Kristin (2016), Social studies learning in elementary schools is expected to facilitate students to gain an understanding of social concepts and be able to train morals, attitudes, skills based on these concepts that have been understood and possessed. Social studies learning is expected to create a pleasant learning atmosphere for students and be able to encourage students to be active. Students need to be active in learning to be able to hone and develop their potential. In accordance with the current curriculum, the learning process in the classroom is designed to be more student-centered so that students are active in constructing or building their knowledge. However, in reality, the implementation of the social studies learning process is currently more dominant in the role of the teacher in it. Referring to the results of research that has been carried out previously by. Kristin (2016) the teacher plays a more active position in explaining the material to students. This will cause student involvement in learning to be less than optimal so that it has an influence on students' understanding which will then have an impact on student learning outcomes.

After making observations at SD Gugus I, Bangli District on October 22, 2019, several problems were found in social studies learning. The problems are 1) learning is still dominated by the role of the teacher who is more active as a provider of material and as a learning resource, 2) during the group discussion process, smart students are more active in dominating while students with moderate or less ability do not take an active role in the group, 3) the lack of media used during learning, the media used by the teacher is only provided from school in a limited number so that students become bored quickly while learning, 4) students are less focused and less active during learning activities, when the teacher asks only a few questions students who want to answer there are even teacher questions that are not answered at all by students, 5) the process of delivering learning material does not begin with the delivery of important concepts from the material to be studied. Many students do not understand learning materials due to differences in students' conceptual understanding of the material presented by the teacher. So that when asked questions, the questions asked by the teacher and those answered by students are not related to each other.

After conducting observations / observations during social studies learning, interviews were also carried out with class V homeroom teachers at SD Gugus I, Bangli District, obtained some data related to the social studies learning process, namely: 1) Learning in class uses a teacher-centered model or direct learning model because the teacher considers students will more easily understand and understand the learning material and the learning process will be completed quickly without requiring a long time; 2) The teacher finds it difficult to determine the appropriate method to increase the active role of all students in the learning process because the teacher does not know innovative methods that can be applied when learning social studies, 3) The teacher rarely uses the media in delivering subject matter because most teachers have a busy schedule so that they do not have enough time to make the media, 4) Students are less active and less focused during learning because of the lack of interest and concentration of students while participating in social studies learning, 5) Students do not understand the learning material because the material coverage is quite broad and dense, so that it has an impact on the students' social studies learning outcomes are low.

In addition to conducting observations and interviews, data collection on students' social studies learning outcomes was also carried out by recording documents. Based on the document recording carried out, data on the social studies learning outcomes of students with Mid-Semester Test scores (UTS) were still relatively low because most students scored below the specified criteria or known as the Minimum Completeness Criteria (KKM). The KKM score and the average UTS score of grade $\mathrm{V}$ students in the social studies subject can be seen in Table 1.

Table1. The Average Score of Class V SD IPS UTS in Cluster I Bangli District Academic Year $2019 / 2020$

\begin{tabular}{|c|c|c|c|c|c|c|c|}
\hline \multirow[b]{2}{*}{ No. } & \multirow[b]{2}{*}{ Schools' Name } & \multirow{2}{*}{$\begin{array}{c}\text { Total } \\
\text { Students }\end{array}$} & \multirow{2}{*}{$\begin{array}{c}\text { Passing } \\
\text { Grade } \\
\text { (KKM) }\end{array}$} & \multicolumn{2}{|c|}{ Completed } & \multicolumn{2}{|c|}{ Not Completed } \\
\hline & & & & Siswa & $\%$ & Siswa & $\%$ \\
\hline 1. & SD N 1 Tamanbali & 30 & 73 & 10 & 33,33 & 20 & 66,67 \\
\hline 2. & SD N 2 Tamanbali & 20 & 70 & 6 & 30 & 14 & 70 \\
\hline 3. & SD N 3 Tamanbali & 19 & 65 & 8 & 42,11 & 11 & 57,89 \\
\hline
\end{tabular}




\begin{tabular}{llcccccc} 
4. & SD N 4 Tamanbali & 14 & 70 & 6 & 42,86 & 8 & 57,14 \\
5. & SD N 1 Bunutin & 17 & 73 & 5 & 29,41 & 12 & 70,59 \\
6. & SD N 2 Bunutin & 22 & 70 & 7 & 31,82 & 15 & 68,18 \\
7. & SD N 3 Bunutin & 16 & 70 & 6 & 37,5 & 10 & 62,5 \\
\hline & Jumlah & 138 & - & 48 & - & 90 & - \\
\hline & & \multicolumn{5}{r}{ (Source: Class V teacher in Cluster I Bangli District) }
\end{tabular}

Based on Table 1. it can be seen that the percentage of students who have completed ranges from $29.41 \%-42.86 \%$, while the percentage of students who have not completed ranges from $57.14 \%-70.59 \%$. This indicates that most students have not fulfilled the KKM. Responding to these problems, efforts should be made to increase student understanding of social studies subject matter which will have a good impact on student learning outcomes. Efforts that can be applied are by applying innovative models that are more focused on developing the participation and active role of students during learning. An innovative learning model that can be applied to create a more enjoyable learning atmosphere and stimulate students to be active is cooperative.

The cooperative learning model is a model that can make all students active during learning and able to train and foster student responsibility, both on themselves and in groups. (Mulyana, et., al., 2016). In the cooperative learning model, students work together with their groups to do group assignments that are given. All students in the group work together so that they can achieve the goals of their group so that all students share responsibility for the success of their group. There are various types of cooperative learning models, one of which is suitable and effective for creating variations in discussion activities, namely the Two Stay Two Stray (TSTS) learning model.

The cooperative learning model with the TSTS type or often called two, only two guests is a type of learning which in its implementation forms students into heterogeneous groups with 4 members of each group (Sari \& Azmi, 2018). The Two Stay Two Stray learning model forms students into small groups of four members, then divided into two students in charge of conveying information or material by remaining in their group and the remaining two students visiting other groups to get information or material (Paramita, et., al., 2016).

With the implementation of learning using this model, students are directed to be active by discussing and working together in groups to work on and solve problems. The steps of the Two Stay Two Stray learning model according to Chotimah (2017): 1) students and their groups of 4 people discuss and work together to complete the assignment; 2) in each group two will be selected to stay and the other two who will be visiting; 3 ) two people who remain in their group are tasked with sharing the results of their group discussions with guests; 4) after completion, guests return to their respective groups to present their findings; 5) groups discuss and match the results of their discussion.

According to Asmarani (2017), The Two Stay Two Stray learning model provides students with opportunities to study together starting from a small scope to larger groups in sharing and exchanging information between groups regarding the subject matter. The adoption of the TSTS cooperative model allows students to exchange opinions and develop social skills such as asking questions and interact with friends during the learning process (Manik \& Gafur, 2016). The Two Stay Two Stray (TSTS) learning model according to (Kadiriandi \& Ruyadi, 2018) has the advantage of being more flexible in its application because it can be used at all levels as well as in various subjects including social studies. The learning process becomes meaningful and more enjoyable because students are facilitated to explore learning material in depth.

The Two Stay Two Stray (TSTS) learning model will be more effective in its application if it is supported by appropriate learning media. The role of the media is very important during learning activities, which is to be a tool that teachers can use to make it easier to convey learning material. Learning media is a tool used to facilitate learning activities to stimulate attention, feelings, thoughts, abilities, and skills so that they can support the learning process (Tafonao, 2018). One of the learning media suitable for integration with the Two Stay Two Stray (TSTS) learning model in social studies subjects is the Mind Mapping media (mind map).

Mind mapping is an image or visual form, from ideas and ideas, so that it is easy to see, show, share, present, and discuss together (Windura in Simanungkalit, 2014). According to Qondias, et., al., (2016) mind mapping or mind map is a technique of making notes by forming patterns of interrelated ideas that are effective when used to bring up hidden ideas that exist in students. With Mind Mappings, students will be easier when conveying ideas, ideas, problems, or whatever is on their mind through a sheet of paper. Mind Mapping media can help students strengthen memory about previously learned information. 
Mind Mapping will make it easier for students and teachers when learning. Students will find it easy to understand the material by focusing on certain parts of a topic. In addition, teachers can find out whether students understand the material and know to what extent students can build and organize that knowledge (Lukman, et., al., 2015). In addition, the existence of a combination of images, colors, symbols, and others will facilitate students to more easily absorb the information obtained because it is easy for students to remember and understand well the material they are learning. This is suitable if used in social studies subjects whose learning contains very dense material.

The use of the Two Stay Two Stray (TSTS) type of cooperative learning model assisted by Mind Mapping media allows students to be more active in learning and can make students better understand the material or topic presented so that student social studies learning outcomes will increase. This is in line with research conducted by Nurhikmayati (2018) which shows that there is a positive influence from the use of Two Stay Two Stray learning on students' mathematical problemsolving abilities. Research from Kumape (2015) also supports this research, which shows that the application of the Two Stay Two Stray model has a significant effect on student learning outcomes in science subjects in grade VI SD Inpres Palupi. In addition, it is also supported by research conducted by Antari (2017) which shows that the competence of the social studies knowledge of students who are taught with the multimedia-assisted TSTS cooperative learning model is higher than students who are not taught the multimedia-assisted TSTS cooperative learning model.

Based on the explanation above, a study entitled "The Effect of the Two Stay Two Stray (TSTS) Type of Cooperative Learning Model Assisted by Mind Mapping Media on Social Studies Learning Outcomes of Class V Elementary School Students in Cluster I Bangli District in the 2019/2020 academic year". The purpose of this study was to determine the significant effect of the Type Two Stay Two Stray (TSTS) Cooperative Learning Model assisted by Mind Mapping Media on the Social Studies Learning Outcomes of Class V Elementary School Students in Cluster I Bangli District in the 2019/2020 academic year.

\section{Research Method}

This research is semi-experimental because it is not possible to strictly control or manipulate all variables. The study design was a nonequivalent post-test only control group design, that was, only using a post-test that was conducted at the end of the study. The population was all objects used in the study (Agung, 2014: 69). The population in this study was all grades V SD in Cluster I Bangli District, amounting to 7 classes with a total of 138 students.

The sample is part of the total population as well as the characteristics contained in that population (Sugiyono, 2011: 81). In this study, the sample was obtained using a simple random sampling technique so that the experimental class was obtained, namely class V SD N 2 Tamanbali with a total of 20 students and a control class namely class V SD N 1 Tamanbali with a total of 30 students. Class V SD N 2 Tamanbali as an experimental class will be given treatment in the form of learning using the Two Stay Two Stray (TSTS) learning model assisted by mind mapping media and in class V SD N 1 Tamanbali as the control class would be given treatment in the form of learning not using the learning model Two Stay Two Stray (TSTS) assisted by mind mapping media. In this study, there was one independent variable, namely the Two Stay Two Stray (TSTS) learning model assisted by mind mapping media, and one dependent variable, namely social studies learning outcomes.

This study used a test method, namely by distributing several instruments to find out the students; social studies learning outcomes. The instrument given was the type of objective test (multiple choice questions) of 30 questions with four options namely a, b, c, and d. The new test was given after the two classes received different treatments in the control class and the experimental class which was called the post-test. To meet the quality of the instruments used, a content validity test or judges test was carried out by experts in the field of social studies, test item validity, test reliability test, test distinguishing power analysis, and difficulty level analysis. The data analysis process in this study used descriptive statistical methods and prerequisite tests for data analysis. The descriptive statistical analysis aimed to calculate the mean, median, mode, variance, and standard deviation.

The prerequisite test for data analysis included the normality test of data distribution and the homogeneity test of variance. The normality test used in this study was the Chi-Square analysis. While the variance homogeneity test used in this study was the Fisher (F) test. The prerequisite test must be carried out before testing the hypothesis. Hypothesis testing in this study used the uncorrelated sample t-test (independent) with the polled variance formula to determine the truth of 
the hypothesis of the effect of the Two Stay Two Stray (TSTS) type of cooperative learning model assisted by mind mapping media on student social studies learning outcomes.

\section{Result and Discussion}

Student social studies learning outcomes are the data collected in this study. The measured learning outcomes are in the cognitive domain obtained from the post-test after holding 7 meetings for each group of students in the experimental or control class. The data from the post-test results were then analyzed using descriptive statistical analysis, prerequisite testing, and hypothesis testing. The results of the descriptive statistical analysis of the research data are presented in table 3.

Table 3. Description of Social Studies Learning Outcomes for the Experiment Group and the Control Group

\begin{tabular}{lll}
\hline Statistics Data & Experiment Group & Control Group \\
\hline Mean & 23,15 & 17,23 \\
Median & 24,5 & 16,83 \\
Modus & 25,94 & 16,5 \\
Variants & 20,03 & 16,12 \\
Standard Deviation & 4,48 & 4,01 \\
Maximum Score & 29 & 25 \\
Minimum Score & 14 & 10 \\
Range & 16 & 16 \\
\hline
\end{tabular}

Based on Table 3, it is known that the average social studies learning outcomes of students in the experimental group were 23.15, while the average social studies learning outcomes of students in the control group was 17.23. Stay Two Stray (TSTS) assisted with mind mapping media was higher than the group of students who did not follow the Two Stay Two Stray (TSTS) type of cooperative learning model assisted by mind mapping media. After the descriptive statistical analysis was carried out, it was continued with the analysis stage with inferential statistics, namely the prerequisite test and the t-test to test the hypothesis. The first prerequisite test is the normality test which is tested using Chi-Square analysis. Based on the results of the analysis in the experimental group, the results obtained were X2-count $=5.15$ and X2-table $=7.815$ with a significance level of $5 \%$ and $\mathrm{dk}=3$, this indicates that X2-count is smaller than X2-table (X2-count \&lt; X2-table) so in the experimental group the data obtained from the post-test results normally distributed. The results of the analysis in the control group obtained the results X2-count $=1.29$ and X2-table $=7.815$ with a significance level of $5 \%$ and $\mathrm{dk}=3$, this shows that X2-count is smaller than X2-table (X2-count \&lt; X2-table) then in the control group the data of the post-test results are obtained normally distributed. The next prerequisite test is the variance homogeneity test using the Fisher Test (F-Test). In the experimental and control groups after the homogeneity test, it was obtained an F-count of 1.24, while F-table was 4.04 (df1 = 1, df2 = 48, with a significance level of 5\%). This means that the value of F-count \&lt; Ftable so that it can be concluded that the post-test results of students in the experimental and control groups have homogeneous variances.

After the data distribution normality test and the variance homogeneity test was carried out, the results showed that the data met the prerequisites so that hypothesis testing could be carried out. To test the hypothesis, the polled variance t-test formula was used.

The results of the t-test analysis of the student social studies learning outcomes data can be seen in table 4.

Table 4. Recapitulation of t-test calculation results

\begin{tabular}{llllll}
\hline Group & $\mathbf{N}$ & $\overline{\boldsymbol{X}}$ & $\mathbf{s}^{\mathbf{2}}$ & t-count & t-table (sig 5\%) \\
\hline Experiment & 20 & 23,15 & 20,03 & 4,89 & 2,010 \\
Control & 30 & 17,23 & 16,12 & & \\
\hline
\end{tabular}

Based on Table 4. the results of the t-test calculation obtained the t-value of 4.89. While t table with degrees of freedom $\mathrm{dk}=48$ at the $5 \%$ significance level is 2.010 . This means that $\mathrm{t}$ is greater than t-table ( $\mathrm{t}$-count> $\mathrm{t}$-table) then $\mathrm{H} 0$ is rejected and $\mathrm{H} 1$ is accepted. Therefore, it can be concluded that there is a significant effect of the Two Stay Two Stray (TSTS) type of cooperative learning model 
assisted by mind mapping media on the social studies learning outcomes of fifth-grade elementary school students in Cluster I Bangli District for the 2019/2020 academic year.

In the experimental group and the control group, it was found that significantly different learning outcomes were due to different treatments given to the learning steps and student discussion activities during learning. The steps of the Two Stay Two Stray (TSTS) learning model assisted by mind mapping media can encourage all students to actively participate in the learning process so that it has a positive effect on student social studies learning outcomes.

The first stage of the Two Stay Two Stray type of cooperative learning model was the stage of group division. At this stage, the students form groups, each of which has 4 members. Students are very enthusiastic about looking for groups based on those directed by the teacher. Students do not seem to discriminate against their friends when choosing groups.

The second stage was giving assignments; at this stage, the teacher provides brief information about the learning material. Students listen carefully to the explanation given by the teacher. Students who do not understand ask questions to the teacher.

The third stage was thinking together, students together with their groups create and complete assignments or problems given by the teacher. Students work on assignments given by discussing with friends in their groups. Students think of the right answers related to the problems presented by the teacher then write them down in the form of a mind mapping. When discussing the students look very enthusiastic to find the appropriate answers to the given topic. Students and their groups can give and receive the opinions that are in their minds. After that students share the task of writing down the results of their thoughts in the form of mind mapping.

The fourth stage was staying or visiting. After finishing discussions and making mind mapping, each group determines two group members who will stay in their group (stay) to share information with other group members and assign two other members to seek and get information from other groups (stray). At this stage, all students actively play their roles, either staying or visiting other groups. Students who explain the material can convey it well and students who receive the material seem to focus on listening to their friends' explanations while taking notes.

The fifth stage is a group discussion. At this stage, all group members in charge of visiting other groups, return to their original groups, then report the things they find and get from other groups. Students discuss and share what they have learned from previous activities.

The sixth stage or the final stage is class discussion. At this stage, the students present a summary of the previous work with the findings obtained. Students present the results of their group negotiations in front of the class based on the direction of the teacher. At this last stage, students can communicate well the conclusions of the material they have obtained.

At the first meeting, the implementation of the Two Stay Two Stray (TSTS) learning model assisted by mind mapping media, the teacher seemed to have difficulty conditioning students to form groups, students became attributes and the class atmosphere became a little rowdy. In addition, during group discussions, there were still students who were shy to express their opinions. However, at the second and subsequent meetings, the teacher was able to condition students to form groups with the teacher's strategy of using counting methods from 1-4. Students who previously were still shy have started to dare to express their opinions and actively participate in doing assignments in their groups. Groups of students who were taught with the Two Stay Two Stray type of cooperative learning model assisted by mind mapping media (experimental group) showed better learning outcomes than those using the previous model.

This is in line with Miftachudin (2015) with the two stay two stray learning model, students' learning achievement is better than the direct learning model. Increased student learning outcomes because the learning process is more student-centered, can increase student interest and enthusiasm while learning and foster a sense of student cooperation. In applying this model, it provides equal opportunities for all students to learn. All students play an active role during learning, not only smart students who dominate. After the second meeting to the seventh meeting, the students were accustomed to following the steps of learning, were accustomed to expressing their opinions, and began to be more creative when making mind maps. This has a positive impact on the average posttest score of the experimental group, which is 23.15 which is in the very high category. These findings indicate that, through Two Stay Two Stray learning assisted by mind mapping media, all students become active in learning and understand material concepts so that they can have a positive effect in improving social studies learning outcomes.

These findings are in accordance with the statement Gumay (2017) The Two Stay Two Stray cooperative model is an alternative in the learning process so that student learning outcomes increase, able to increase student interest and motivation, and be able to create a pleasant learning 
atmosphere. With the two stay two stray learning model, students can increase student selfconfidence, make students more courageous in expressing opinions, develop cohesiveness with groups, improve student speaking skills, and increase student motivation, achievement, and interest in learning (Shoimin, 2014).

In this study, the role of Mind Mapping media is also very influential in learning. Using mind mapping as a learning medium can increase student interest in learning and affect student achievement (Lubis, 2018). Mind mapping media can optimize the performance of the left brain and right brain because it combines writing, relationships between words, writing order, colors, images, and shapes (Rahardian, et., al., 2019). With mind mapping students are invited and trained to read, take notes, and listen to explanations from other students or teachers then convey their ideas, ideas and knowledge on a sheet of paper. That way students can understand the learning material well and have a stronger memory of the material that has been studied. Students' understanding of the material being taught has a positive impact on student learning outcomes, especially in social studies subjects.

The results of this study are in accordance with the research conducted by Suarthika, (2017) which states that the Two Stay Two Stray learning model has an effect on conceptual understanding in the social studies subjects of fifth-grade elementary school students in Gugus IV, Selemadeg Timur District, 2016/2017 Academic Year. In addition, it is also in accordance with the research conducted by Diarsa (2017) which shows that there is a positive effect of the Two Stay Two Stray learning model assisted by visual media on the science learning outcomes of grade V SD students in the Bangli District Cluster in the 2016/2017 academic year. Research conducted by Dewi (2017) This research also supports this research, the results of this study state that the competence of students' natural science knowledge taught with the Two Stay Two Stray type of cooperative learning model assisted by audio-visual media is higher than those who are not taught with the Two Stay Two Stray type of cooperative learning model assisted by audio-visual media. In addition, this study is also in line with research by Sutrisna(2017) which shows that students' social studies learning outcomes improved after being taught the Two Stay Two Stray type cooperative learning model in grade IV SD Negeri 010 Silikuan Hulu.

Based on the results of the analysis that has been carried out and supported by the results of previous studies, the Two Stay Two Stray (TSTS) type of cooperative learning model assisted by mind mapping media affects the social studies learning outcomes of grade V SD students in Cluster I Bangli District for the 2019/2020 academic year.

\section{Conclusion}

Based on the previous explanation, this study concludes that there is a significant effect of the Two Stay Two Stray (TSTS) type of cooperative learning model assisted by mind mapping media on the social studies learning outcomes of grade V SD students in Cluster I Bangli District in the $2019 / 2020$ academic year. Suggestions that can be conveyed include students so that they can participate in classroom learning activities properly and be able to actively participate in the learning process. It is recommended that teachers be able to innovate in the learning process by applying innovative models in learning and supported by suitable and appropriate learning media to make students interested and active in learning so that student social studies learning outcomes can increase. It is recommended that the principal be able to determine a policy to implement an effective and fun learning model in schools such as the Two Stay Two Stray learning model assisted by mind mapping media, especially schools where students have problems with social studies learning outcomes. It is recommended for other researchers who will carry out similar research so that this research can be a reference as well as a consideration for the improvement and improvement of the research to be carried out.

\section{References}

Agung, A. A. G. (2014). Metodelogi Penelitian Pendidikan. Malang: Aditya Media Publishing.

Antari, N. L. P. Y., dkk. 2017. Pengaruh Model Pembelajaran Kooperatif Tipe Two Stay Two Stray (TSTS) Berbantuan Multimedia Terhadap Kompetensi Pengetahuan IPS Siswa Kelas V SD Gugus Letda Made Putra. e-Journal PGSD Universitas Pendidikan Ganesha, Volume 5, No. 2. http://dx.doi.org/10.23887/jjpgsd.v5i2.10649 
Asmarani, D. (2017). Pembelajaran Kooperatif Model Two Stay With Question Roll Untuk Meningkatkan Hasil Belajar Siswa Di Smpn II Singosari Malang. Jurnal Dinamika Penelitian, 1, 53. http://ejournal.iain-tulungagung.ac.id/index.php/dinamika/article/view/831/575

Chotimah, H. (2017). Peningkatan Keterampilan Diskusi Siswa Kelas X SMAN 1 Pleret, Bantul Melalui Model Pembelajaran. 8(1), 29-40. https://jiesjournal.com/index.php/jies/article/view/84

Christina, L. V., \& Kristin, F. (2016). Efektivitas Model Pembelajaran Tipe Group Investigation (Gi) Dan Cooperative Integrated Reading and Composition (Circ) Dalam Meningkatkan Kreativitas Berpikir Kritis Dan Hasil Belajar Ips Siswa Kelas 4. Scholaria: Jurnal Pendidikan Dan Kebudayaan, 6(3), 217. https://doi.org/10.24246/j.scholaria.2016.v6.i3.p217-230

Dewi, N.N.R. dkk. (2017). Pengaruh Model Pembelajaran Kooperatif Tipe Two Stay Two Stray Berbantuan Media Audio Visual Terhadap Kompetensi Pengetahuan Ipa Siswa Kelas V Sd Gugus Letda Made Putra. MIMBAR PGSD Undiksha, 5(2). http://dx.doi.org/10.23887/jjpgsd.v5i2.10650

Diarsa, I. P. (2017). Pengaruh Model Pembelajaran Two Stay Two Stray Terhadap Hasil Belajar IPA Siswa. Mimbar PGSD Universitas Pendidikan Ganesha, 5(2), 3. http://dx.doi.org/10.23887/jjpgsd.v5i2.10928

Fajarini, A. (2018). Desain pembelajaran ips berbasis media. Tarbiyatuna, 2(2), 19-30. http://webcache.googleusercontent.com/search?q=cache:5i2x ItT2Qc):ejournal.iaiibrahimy. ac.id/index.php/tarbiyatuna/article/view/159/183+\&cd=1\&hl=en\&ct=clnk\&gl=id

Gumay, O. P. U. (2017). Pengaruh Model Pembelajaran Kooperatif Tipe Two Stay Two Stray terhadap Hasil Belajar Fisika Siswa Kelas 8 SMP Negeri 3 Lubuklinggau. Science and Physics Education Journal (SPEJ), 1(1), 49-58. DOI: 10.31539/spej.v1i1.102

Kadiriandi, R., \& Ruyadi, Y. (2018). Pengaruh Penerapan Model Pembelajaran Model Two Stay Two Stray (Tsts) Terhadap Peningkatan Keaktifan Dan Hasil Belajar Sosiologi Di Sma Pasundan 3 Bandung. Sosietas, 7(2), 429-433. https://doi.org/10.17509/sosietas.v7i2.10362

Kristin, F. (2016). Efektivitas Model Pembelajaran Kooperatif Tipe Stad Ditinjau Dari Hasil Belajar Ips Siswa Kelas 4 Sd. Scholaria: Jurnal Pendidikan Dan Kebudayaan, 6(2), 74. https://doi.org/10.24246/j.scholaria.2016.v6.i2.p74-79

Kumape, S. (2015). Pengaruh Penerapan Model Pembelajaran Kooperatif Tipe Two Stay Two Stray Terhadap Aktivitas dan Hasil Belajar Siswa Tentang IPA di Kelas VI SD Inpres Palupi. Jurnal Kreatif Todulako Online, 4(4), 351-362. http://jurnal.untad.ac.id/jurnal/index.php//KTO/article/view/6131

Lubis, F. A. (2018). Pengaruh Penerapan Strategi Pembelajaran Inkuiri Divariasikan Dengan Media Mind Mapping Terhadap Minat Belajar Siswa. Jurnal Biolokus, 1(2), 93. http://dx.doi.org/10.30821/biolokus.v1i2.349

Lukman, L., Martini, K., \& Utami, B. (2015). Efektivitas Metode Pembelajaran Project Based Learning (Pjbl) Disertai Media Mind Mapping Terhadap Prestasi Belajar Siswa Pada Materi Pokok Sistem Koloid Di Kelas Xi Ipa Sma Al Islam 1 Surakarta Tahun Ajaran 2013/2014. Jurnal Pendidikan Kimia Universitas Sebelas Maret, 4(1), 113-119. https://media.neliti.com/media/publications/121739-ID-none.pdf

Manik, K., \& Gafur, A. (2016). Penerapan Model Two Stay Two Stray Berbantuan Multimedia Untuk Meningkatkan Aktivitas Dan Hasil Belajar Ips. Harmoni Sosial: Jurnal Pendidikan IPS, 3(1), 3949. https://doi.org/10.21831/hsjpi.v3i1.9693

Miftachudin, B. \& R. (2015). Efektivitas Model Pembelajaran Two stay Two Stray Dengan Tutor Sebaya Dalam Pembelajaran Matematika Pada Materi BangunDatar Ditinjau Dari Kecerdasan Majemuk Peserta Didik Kelas VII SMP Negeri Di Kebumen Tahun Pelajarn 2013/2014. Jurnal Elektronik Pembelajaran Matematika, 3(3), 233-241. https://jurnal.uns.ac.id/jpm/article/view/10648/0

Mulyana, M. A., Hanifah, N., Jayadinata, A. K., \& Kunci, K. (2016). Penerapan Model Kooperatif Tipe Numbered Heads Together (NHT) Untuk Meningkatkan Hasil Belajar Siswa Pada Materi Kenampakan Alam Dan Sosial Budaya. Penerapan Model Kooperatif Tipe Numbered Heads 
Together (NHT) Untuk Meningkatkan Hasil Belajar Siswa Pada Materi Kenampakan Alam Dan Sosial Budaya, 1(1), 331-340. https://doi.org/10.23819/pi.v1i1.3039

Nurhasanah, A. (2016). Penggunaan Metode Simulasi Dalam Pembelajaran Keterampilan Literasi Informasi Ips Bagi Mahasiswa Pgsd. Jurnal Pendidikan Sekolah Dasar, 2(1), 87-95. http://dx.doi.org/10.30870/jpsd.v2i1.670

Nurhikmayati, I. (2018). Pengaruh Model Two Stay Two Stray Terhadap Kemampuan Pemecahan Masalah Matematik Siswa. Jurnal Theorems (The Original Research of Mathematics, 3(1), 4957. http://dx.doi.org/10.31949/th.v3i1.895

Paramita, N. P. I., Ardana, I. K., \& Putra, I. K. A. (2016). Pengaruh Model Pembelajaran Two Stay Two Stray Berbantuan Peta Konsep Terhadap Hasil Belajar IPS Siswa Kelas V SD Gugus I Kecamatan Gianyar Tahun 2015/2016. Jurnal Mimbar PGSD Universitas Pendidikan Ganesha, 4(1), 1-10. http://dx.doi.org/10.23887/jipgsd.v4i1.7052

Qondias, D., Anu, E. L., \& Niftalia, I. (2016). Pengembangan Media Pembelajaran Tematik Berbasis Mind Maping Sd Kelas Iii Kabupaten Ngada Flores. JPI (Jurnal Pendidikan Indonesia), 5(2), 176. http://dx.doi.org/10.23887/jpi-undiksha.v5i2.8590

Rahardian, D., Wijanarko, T., Putra, A., \& Hakim, F. N. (2019). Perancangan Media Pembelajaran Tata Surya Berbasis Multimedia dengan Metode Mind Mapping untuk Siswa Kelas IX SMP $\begin{array}{lllll}\text { Muhammadiyah } & 3 & \text { Kaliwungu. } & 12(2), & \text { 1-9. }\end{array}$ https://journal.stekom.ac.id/index.php/elkom/article/view/29

Sari, A., \& Azmi, M. P. (2018). Penerapan Model Kooperatif Tipe Two Stay Two Stray (Tsts) Terhadap Kemampuan Komunikasi Matematis. Jurnal Cendekia : Jurnal Pendidikan Matematika, 2(1), 164-171. https://doi.org/10.31004/cendekia.v2i1.42

Shoimin, A. (2014). 68 Model Pembelajaran Inovatif dalam Kurikulum 2013. Yogyakarta: Ar-Ruzz Media.

Simanungkalit, N. A. dan H. T. (2014). Pengaruh Penggunaan Media Pembelajaran Mind Mapping Terhadap Prestasi Belajar Matematika Siswa Kelas VII SMP Tunas Baru Jin-Seung Batam Tahun Ajaran 2014/2015. Jurnal Pythagoras, 2(1), 32-37. http://dx.doi.org/10.33373/pythagoras.v5i1.237

Suarthika, I.M. dkk. (2017). Pengaruh Model Pembelajaran Two Stay Two Stray Terhadap Pemahaman Konsep Pada Mata Pelajaran Ips. MIMBAR PGSD Undiksha. 5(3). http://dx.doi.org/10.23887/jipgsd.v5i3.12431

Sugiyono. (2011). Metode Penelitian Kuantitatif, Kualitatif dan R \& D. Bandung: Alfabeta.

Sutrisna, E. (2017). Penerapan Model Pembelajaran Kooperatif tipe Two Stay Two Stray, Hasil Belajar IPS. Jurnal Primary Program Studi Pendidikan Guru Sekolah Dasar Fakultas Keguruan Dan Ilmu Pendidikan Universitas Riau, 172-189. https://media.neliti.com/media/publications/258292-penerapan-model-pembelajarankooperatif-6b18a268.pdf

Sutrisno, V. L. P., \& Siswanto, B. T. (2016). Faktor-Faktor Yang Mempengaruhi Hasil Belajar Siswa Pada Pembelajaran Praktik Kelistrikan Otomotif Smk Di Kota Yogyakarta. Jurnal Pendidikan Vokasi, 6(1), 111. https://doi.org/10.21831/jpv.v6i1.8118

Tafonao, T. (2018). Peranan Media Pembelajaran Dalam Meningkatkan Minat Belajar Mahasiswa. Jurnal Komunikasi Pendidikan, 2(2), 103. https://doi.org/10.32585/jkp.v2i2.113 